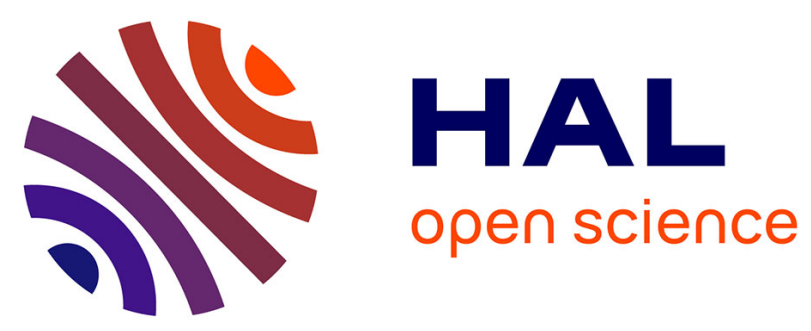

\title{
Wetland dynamics using a suite of satellite observations: A case study of application and evaluation for the Indian Subcontinent.
}

\author{
F. Papa, Christophe Prigent, Franck Durand, W. B. Rossow
}

\section{- To cite this version:}

F. Papa, Christophe Prigent, Franck Durand, W. B. Rossow. Wetland dynamics using a suite of satellite observations: A case study of application and evaluation for the Indian Subcontinent.. Geophysical Research Letters, 2006, 33, pp.L08401. 10.1029/2006GL025767 . hal-00280336

\section{HAL Id: hal-00280336 https://hal.science/hal-00280336}

Submitted on 2 Apr 2021

HAL is a multi-disciplinary open access archive for the deposit and dissemination of scientific research documents, whether they are published or not. The documents may come from teaching and research institutions in France or abroad, or from public or private research centers.
L'archive ouverte pluridisciplinaire HAL, est destinée au dépôt et à la diffusion de documents scientifiques de niveau recherche, publiés ou non, émanant des établissements d'enseignement et de recherche français ou étrangers, des laboratoires publics ou privés. 


\title{
Wetland dynamics using a suite of satellite observations: A case study of application and evaluation for the Indian Subcontinent
}

\author{
Fabrice Papa, ${ }^{1}$ Catherine Prigent, ${ }^{2}$ Fabien Durand, ${ }^{3}$ and William B. Rossow ${ }^{1}$ \\ Received 13 January 2006;* revised 10 March 2006; accepted 16 March 2006; published 19 April 2006.
}

[1] Using a suite of satellite observations, including passive and active microwave along with visible and infrared observations developed to estimate wetlands on a global scale, the present study examine wetlands spatial and temporal dynamics over the Indian subcontinent, a region subject to an annual monsoon. Monthly wetlands extent estimates over a 2-year (1993-1994) period and their consistency are analyzed using independent data sets, such as rainfall rate in-situ rain-gauge observations and the Global Precipitation Climatology Project product, as well as river water levels derived from radar altimeter observations. The extent variations show a good agreement with the raingauge data, a high correlation with the GPCP rain data and a similar seasonal cycle with the altimeter estimates over the 2 years. This case study evaluation shows the potential of the remote sensing to give spatial-temporal consistent information on the variability of flooded areas and encourages the development of longer satellite wetlands estimates. Citation: Papa, F., C. Prigent, F. Durand, and W. B. Rossow (2006), Wetland dynamics using a suite of satellite observations: A case study of application and evaluation for the Indian Subcontinent, Geophys. Res. Lett., 33, L08401, doi:10.1029/2006GL025767.

\section{Introduction}

[2] Wetlands and inundated areas (including rice paddies) are estimated to occupy around $8.6 \times 10^{6} \mathrm{~km}^{2}$ of the Earth's surface, out of which about $4.8 \times 10^{6} \mathrm{~km}^{2}$ are located in the tropics and sub-tropics [Clarke, 1994]. Although they only cover $\sim 6 \%$ of the Earth's ice-free land surface, they play a major role in hydrological and biochemical cycles.

[3] First, they represent the world's largest methane source $\left(\mathrm{CH}_{4}\right)$, the only one dominated by climate variations, accounting for $\sim 40 \%$ of $\mathrm{CH}_{4}$ emitted annually to the atmosphere [Walter et al., 2001]. Second, wetlands play a key role in local hydrological systems. They regulate river hydrology and a part of the fresh water input to oceans by river discharge is processed through them. For instance, in the north Indian Ocean, especially in the Bay of Bengal, river discharge contributes significantly to the observed low salinity, which plays a critical role in modulating sea surface temperature [Durand et al., 2004]. Finally, wetlands also

\footnotetext{
${ }^{1}$ NASA Goddard Institute for Space Studies, Columbia University, New York, New York, USA.

${ }^{2}$ Laboratoire d'Étude du Rayonnement et de la Matière en Astrophysique - Centre National de la Recherche Scientifique, Observatoire de Paris, Paris, France.

${ }^{3}$ Institut de Recherche Pour le Développement/Laboratoire d'Études en Géophysique et Océanographie Spatiales, UMR 5566, Toulouse, France.
}

Copyright 2006 by the American Geophysical Union. 0094-8276/06/2006GL025767 have the capacity to retain excess floodwater during heavy rainfall events that would otherwise cause flooding; periodically inundated wetlands are very effective in storing rainwater, providing the source for recharching ground water supplies [Ramachandra, 2001].

[4] Approximately $60 \%$ of wetlands are inundated only during some portion of the year, leading to large seasonal and interannual variability of their extents. This is particularly true for the Indian subcontinent, which is subject to an annual monsoon [Shaman et al., 2005] and also receives water from the Himalayan snow melt. Human activities in this densely populated region are critically dependent on this hydrological cycle.

[5] Reliable and timely information about the extent, spatial distribution and temporal variation of wetlands is crucial to better understand their influence on regional hydrology, as well as to contribute to water resources management and to regional alert systems on flood hazards. Characterizing wetlands and their dynamics over a large geographical region has been investigated using different techniques with varying degrees of success. Data sets are available based on soil and vegetation classifications providing estimations of global wetland distributions [Matthews and Fung, 1987; Matthews et al., 1991], but do not provide information on the temporal and spatial dynamics. Satellite observations provide a means of monitoring wetlands and their dynamics at global and regional scales over long time periods. Hence, remote sensing (RS) techniques are being actively explored [Smith, 1997]. A globally applicable RS technique, using a suite of complementary satellite observations, was developed to quantify spatial and temporal dynamics of wetlands [Prigent et al., 2001a]. It is based on the detection of inundation using passive microwave land-surfaces emissivitie estimated from SSM/I observations, together with ERS scatterometer and AVHRR visible and near infrared reflectances to estimate the vegetation contribution to the passive microwave signal [Prigent et al., 2001a, 2001b]. This and other methods were compared with multiple independent data sets, but the validation did not include evaluation of the seasonal dynamics [Prigent et al., 2001a]. The objective of the present study is to demonstrate the capability of this suite of satellite observations to recover wetland extents and dynamics over the specific well-observed region of the Indian subcontinent and to check the consistency of the new estimates using independent variables such as rainfall from rain-gauges or from models and water levels observations.

\section{Data and Methodology}

[6] The initial evaluation of the methodology developed to quantify the extent and seasonality of inundation on the

*The received date is correct here. The article as originally published is online. 


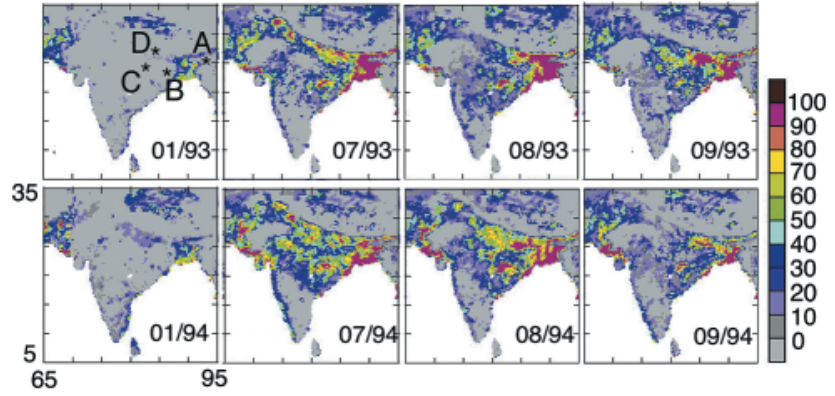

Figure 1. Monthly fractional inundation of wetlands (\%) from RS estimates for January, July, August and September 1993 and 1994 over the Indian subcontinent on a $0.25^{\circ}$ equal-area grid.

global scale with a suite of satellites is described by Prigent et al. [2001a]. The selected satellite observations used to detect wetlands cover a large wavelength range: a) passive microwave SSM/I emissivities at $37 \mathrm{GHz}(0.81 \mathrm{~cm})$; b) ERS-1 active microwave scatterometer backscatter at $5.25 \mathrm{GHz}(5.71 \mathrm{~cm})$; c) AVHRR Normalized Difference Index Vegetation NDVI. A full description of each satellite observation is given by Prigent et al. [2001b] which illustrates clearly that the instruments are complementary and underlines the potential of merged satellite data to study wetlands.

[7] As a first step, all remote sensing data are monthly averaged in an equal area resolution of $0.25^{\circ}$ at the equator (a pixel equals to $773 \mathrm{~km}^{2}$ ) for the period 1993-1994. The proposed methodology to estimate monthly flooded areas is then based on the estimation of pixel fractional coverage by open water using the passive microwave signal and a linear mixture model with end-members calibrated with radar observations to account for the effects of vegetation cover [Prigent et al., 2001a].

[8] Three other data sets are used to check the consistency of satellite results for wetlands extent over India for the two years of study: 1) The Indian regional monthly rainfall from rain-gauge stations data set, 2) the GPCP rainfall database and 3) the river water level derived from Topex-Poseidon radar altimeter observations. These data sets are independent (see below) and offer a reliable time evolution to compare with.

[9] The rain-gauge data set is based on in-situ observations collected over a hundred years [Parthasarathy et al., 1995]. The data used are monthly rainfall amounts and represent the spatial mean over 4 specific regions. The number of stations used to compute the spatial mean of a specific region (shown in Figure 1) is 10 stations for the Assam region (A), 11 stations for the West Bengal region (B), 8 stations for the East Maddya Pradesh (C) and 21 stations for the West Uttar Pradesh Plains (D).

[10] The Global Precipitation Climatology Project (GPCP) established in 1986 by the World Climate Research Program provides data that quantify the distribution of precipitation over the whole globe [Adler et al., 2003]. Two sources of GPCP Version 2 data are used in our study: the intermediate Multi-satellite products and the SatelliteGauge Combined Precipitation Data product. The intermediate Multi-satellite product is used because it is independent from the Indian regional monthly rainfall from rain-gauge stations data set. The Satellite-Gauge Combined Precipitation Data product, which combines the satellite and gauge data, is used in the last part of the study to help the analysis when comparing the wetland extents with the altimeter observations. GPCP products are monthly means with an initial spatial resolution of $2.5^{\circ}$ of latitude and longitude but regridded on a $0.25^{\circ}$ equal area.

[11] The other RS data set derived from Topex-Poseidon radar altimeter, provides a long time series of water-level large bodies (rivers, lakes) thanks to a specific retracking and data treatment [Fung and Cazenave, 2001]. The altimeter observations described by Gennero et al. [2005] are used for seven locations over two main rivers, the Ganges and the Bramahpoutra.

\section{Results and Discussion}

\subsection{Wetlands Extent}

[12] Figure 1 shows the estimated wetland extents (in percent) for January, July, August and September 1993 and 1994 over the Indian subcontinent. The wetlands extent (the method does not distinguish between natural wetlands, irrigated rice fields and large lakes/rivers) exhibits realistic structures and seasonal variations, especially the ones related to large rivers such as the Ganges, the Bramahputra and the Indus and over central India. These results are in good agreement with Matthew's wetlands spatial structures, especially over the northern and central India [Matthews and Fung, 1987] (not shown). The Matthews and Fung [1987] data do not reflect seasonal dynamics and come from aeronautical charts, which is more likely acquired during the warm seasons of maximum flooding. Our results also well capture the rice paddy signature that mainly dominates the agricultural landscapes reported by Matthews et al. [1991] derived from area statistics and a crop calendar.

[13] Figure 2 displays the seasonal variations of the inundated areas $\left(\mathrm{km}^{2}\right)$ over the area $(5 \mathrm{~N} 35 \mathrm{~N} 65 \mathrm{E} 95 \mathrm{E})$ for the 24 months. The wetlands first appear in May-June, persist for 5 months and disappear in October. The new results are consistent with the absolute estimates and the seasonal variations given by Matthews and Fung [1987] and Matthews et al. [1991].

\subsection{Wetland Extents and Rainfall}

[14] Figure 1 suggests that wetland extents are larger over Central India for July-August 1994 than for 1993 for the same season. Over the northeastern part in the Ganges

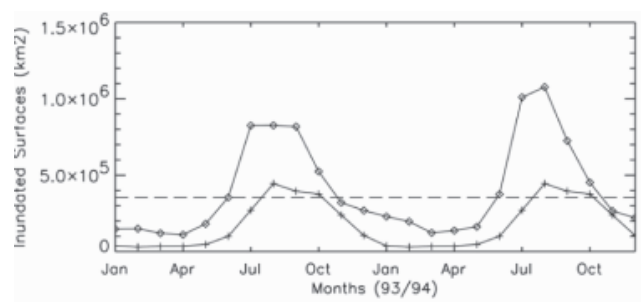

Figure 2. Seasonal variations of the inundated areas $\left(\mathrm{km}^{2}\right)$ over India $\left(5^{\circ} \mathrm{N}-35^{\circ} \mathrm{N} / 65^{\circ} \mathrm{E}-95^{\circ} \mathrm{E}\right)$ for 1993 and 1994. Natural wetlands from Matthews and Fung [1987] (dashed line) and rice fields from Matthews et al. [1991] (cross) are also displayed. 
Table 1. Monthly Rainfall (mm Month ${ }^{-1}$ ) From Rain-Gauge Stations for Different Locations Over India for 1993 and 1994 ${ }^{\mathrm{a}}$

\begin{tabular}{lccccc}
\hline & Year & June & July & August & Sept \\
\hline Assam region & 1993 & 622.0 & 654.6 & 490.1 & 286.8 \\
West Bengal region & 1994 & 390.8 & 321.1 & 315.1 & 293,3 \\
& 1993 & 395.1 & 654.1 & 475.5 & 364.0 \\
East Maddya Pradesh region & 1994 & 354.5 & 321.1 & 407.0 & 275.2 \\
& 1993 & 123.4 & 244.8 & 304.0 & 397.8 \\
West Uttar Pradesh Plains & 1994 & 306.7 & 566.1 & 529.9 & 155.7 \\
& 1993 & 86.4 & 161.5 & 141.8 & 273.8 \\
& 1994 & 51.8 & 367.7 & 232.6 & 214.9 \\
\hline
\end{tabular}

${ }^{\mathrm{a}}$ The regions are located on Figure 1.

drainage basin, the fractional extent of wetlands is estimated to be larger in the summer 1993 than 1994. The same differences are seen in the monthly rainfall from rain-gauge stations reported on Table 1.

[15] The second comparison is with the GPCP Multisatellite data set. The linear correlations of point time records have been computed over the whole Indian subcontinent between the RS wetland extent estimations and the GPCP multi-satellite rainfall product for the 24 months of 1993 and 1994. The results are mapped in Figure 3. The correlations are highly significant and have the expected signs with rather large values.

[16] Over central India, the correlation coefficients are $>0.8$. Along river basins such as the Ganges or the Indus, the correlation coefficients range mainly between 0.6 and 0.9. Over the Southern Ganges bank and its delta in Bangladesh, the correlation coefficients mainly are much lower, between 0.2 and 0.6 . In the case of such wetlands connected with a large hydrographic network and fed by a large upstream basin, such as the Ganges River, wetland flooding does not depend on local rainfall, but on the overall river basin hydrology and rainfall over the upstream basin. Moreover, rice paddies dominate the agricultural landscapes in the Delta and they have a dynamic that is partly disconnected from rainfall. Over the Southern West coast, the correlation coefficients are low and even negative (between -0.2 and 0.2 ); even though this region receives large amounts of rain; it is mainly composed of small mountains (Western Ghats) and their varying slopes may limit the use of the RS technique.

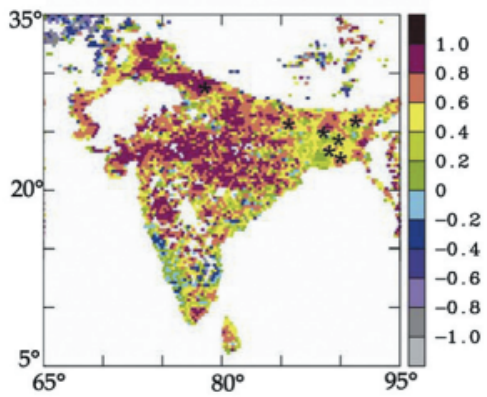

Figure 3. Linear correlation coefficients map of the RS monthly estimates of fractional extent of wetlands and the monthly GPCP rain rates from the intermediate multisatellite products for 1993-1994. The p-value equal 0.5 above a correlation of 0.34 .
[17] We also performed a sensitivity study using the GPCP Satellite-Gauge Combined Precipitation Data product instead of GPCP Multi-satellites product in the wetlandsrainfall extent correlation computation (not shown). The results are consistent with slightly higher correlations over the deltas (of order 0.6, not shown).

\subsection{Wetland Extents and Rivers Level Data}

[18] In this section, the wetland extent variations for the 2-years are compared with water level estimates derived from satellite altimeter observations. The wetland extent estimations are averaged for a $1^{\circ} \times 1^{\circ}$ region around the altimeter measurement locations. Figure 4 displays the normalized two year time series over 7 different points located along the largest rivers of the Indian continent. These areas are indicated by stars on Figure 3. The GPCP Satellite-Gauge Combined Precipitation Data product is also displayed to help the interpretation; it is also averaged as well on a $1^{\circ} \times 1^{\circ}$ pixel around the altimeter measurements.

[19] First, Figure 4 clearly shows a strong agreement among the three data sets in the seasonal cycle over the two years. In Figures 4a, 4b, 4c and 4f, we see the three data sets increasing from May and reaching a maximum in JulyAugust with a period of inundation of around 6 months.

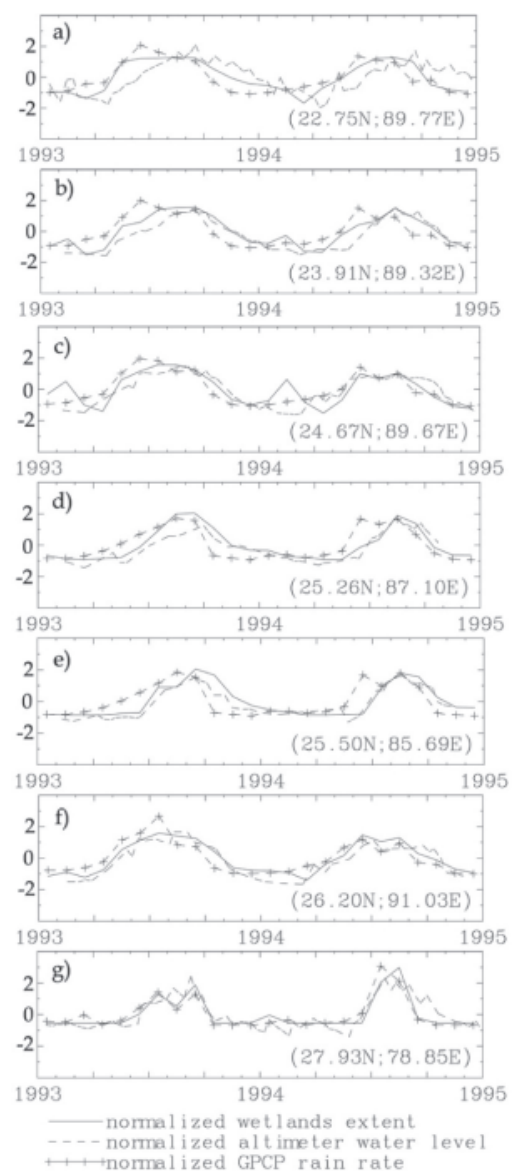

Figure 4. Temporal profiles from January 1993 to December 1994 of normalized wetlands extent and normalized river water level for 7 large river locations. The normalized GPCP rain rates from the Satellite-Gauge Combined Precipitation Data product are also displayed. 
Figures $4 \mathrm{~d}, 4 \mathrm{e}$ and $4 \mathrm{~g}$ show shorter periods of heavy inundation, river level rise and rainfall amounts.

[20] In the eastern part of the Ganges River basin and Bramahpoutra River (Figures 4a, 4b, 4c, and 4d), we observe a longer period of inundation and high rain rate with larger peak values in 1993 than in 1994 that agrees with previous observations from rain-gauges discussed in part III. b. Moreover, on Figure 4g, the western part on the Ganges River, 1994 has larger peak values than 1993 as noted before.

[21] In the time records in Figures $4 a, 4 b$ and $4 d$, we note a time-lag of about two months when comparing the wetlands extent and the altimeter river level; consistent with a spreading of the water, in the deltas regions, before being drained by the river. A time difference is also observed between the wetland extents and the GPCP rain data profiles, especially on Figures 4d and 4e for 1994.

[22] In Figure 4c, we note an increase of wetland extent at the beginning of 1994 that is not associated with either increases in GPCP or the altimeter. This result could indicate some limitation of the methodology during some parts of the year related to vegetation effects or soil that is already saturated with water.

\section{Conclusion and Perspective}

[23] This study reports a first effort to quantify and evaluate seasonality and extent of wetlands and inundations using a suite of satellites over the Indian subcontinent. Inundated areas for natural wetlands, irrigated rice fields and lake/rivers are comparable and consistent with independent data sets such as rain-gauge stations over India, GPCP version 2 products or river level from radar altimeter measurements.

[24] Given the promising preliminary results presented here, which indicates that consistent wetlands dynamics estimates are possible by using this RS technique, it is important to extend this study to a much larger time period that will allow the study of interannual variability of the monsoon rain in India and the resulting hydrological processes. Comparison could also be made with observed variations of mountains snow cover. There are a number of factors that affect the run-off of precipitation than can vary in importance with location and season, such a long term data set combination can enhance our understanding of the role of the factors in such region and over the globe.
[25] Acknowledgments. This work is supported in part by the PROFIRMEC in the frame of the HYDISC project. The authors thank Shankar D. and Shenoi S. S. from the National Institute of Oceanography, Goa, India for their useful comments. The Indian regional monthly rainfall data set was provided by the Indian Institute of Tropical Meteorology.

\section{References}

Adler, R. F., et al. (2003), The Version 2 Global Precipitation Climatology Project (GPCP) monthly precipitation analysis 1979 -present, J. Hydrometeorol., 4, 1147-1167.

Clarke, R. (1994), The pollution of lakes and reservoirs, UNEP Environ. Libr. 12, U. N. Environ. Program, Nairobi, Kenya.

Durand, F., S. R. Shetye, J. Vialard, D. Shankar, S. S. C. Shenoi, C. Ethe, and G. Madec (2004), Impact of temperature inversions on SST evolution in the South-Eastern Arabian Sea during the pre-summer monsoon season, Geophys. Res. Lett., 31, L01305, doi:10.1029/2003GL018906.

Fung, L. L., and A. Cazenave (2001), Satellite Altimetry and Earth Science: A Handbook of Techniques and Application, Elsevier, New York.

Gennero, M. C., J. F. Cretaux, M. Berge NGuyen, C. Maheu, K. Do Minh, S. Calmant, and A. Cazenave (2005), Surface water monitoring by satellite altimetry, Lab. d'Etudes en Geophys. et Oceanogr. Spatiales, Toulouse, France. (Available at http://legos.obs-mip.fr/soa/hydrologie/ hydroweb/.)

Matthews, E., and I. Fung (1987), Methane emission from natural wetlands: Global distribution, area, and environmental characteristics of sources, Global Biogeochem. Cycles, 1, 61-86.

Matthews, E., I. Fung, and J. Lerner (1991), Methane emission from rice cultivation: Geographic and seasonal distribution of cultivated areas and emissions, Global Biogeochem. Cycles, 5, 3-24.

Parthasarathy, B., A. A. Munot, and D. R. Kothawale (1995), All India monthly and seasonal rainfall series: 1871-1993, Theor. Appl. Climatol., 49, 217-244

Prigent, C., E. Matthews, F. Aires, and W. B. Rossow (2001a), Remote sensing of global wetland dynamics with multiple satellite data sets, Geophys. Res. Lett., 28, 4631-4634.

Prigent, C., F. Aires, W. B. Rossow, and E. Matthews (2001b), Joint characterization of vegetation by satellite observations from visible to microwave wavelength: A sensitivity analysis, J. Geophys. Res., 106, $20,665-20,685$

Ramachandra, T. V. (2001), Restoration and management strategies of wetlands in developing countries, Electr. Green J., 15, 1-15.

Shaman, J., M. Cane, and A. Kaplan (2005), The relationship between Tibetan snow depth, ENSO, river discharge and the monsoon of Bangladesh, Int. J. Remote Sens., 26, 3735-3748.

Smith, L. C. (1997), Satellite remote sensing of river inundation area, stage and processes: A review, Hydrol. Proc., 11, 1427-1439.

Walter, B., M. Heinmann, and E. Matthews (2001), Modeling modern methane emission from natural wetlands, 1 . Model description and results, J. Geophys. Res., 106, 34,189-34,206.

F. Durand, IRD/LEGOS-UMR 5566, 14 Avenue Edouard Belin, F-31400 Toulouse, France.

F. Papa and W. B. Rossow, NASA Goddard Institute for Space Studies, Columbia University, 2880 Broadway, New York, NY 10025, USA. (fpapa@giss.nasa.gov)

C. Prigent, LERMA-CNRS-Observatoire de Paris, 61 Av. de l'Observatoire, F-75014 Paris, France. 